\title{
Addressing Environmental Change through Emergent Integrated Environmental Observatories: A Case Study in the Czech Republic
}

\author{
Manuel Acosta ${ }^{1, *}$, Alexander Ač ${ }^{1}$, Marian Pavelka ${ }^{1,2}$, Kateřina Havránková ${ }^{1}$, \\ Henry W. Loescher ${ }^{3,4}$, James H. Butler ${ }^{5}$, Dalibor Janouš ${ }^{1}$ and Michal V. Marek ${ }^{1}$ \\ 1 Department of Matters and Energy Fluxes, Global Change Research Institute, CAS, Brno 60300, \\ Czech Republic; ac.a@czechglobe.cz (A.A.); pavelka.m@czechglobe.cz (M.P.); \\ havrankova.k@czechglobe.cz (K.H.); janous.d@czechglobe.cz (D.J.); marek.mv@czechglobe.cz (M.V.M.) \\ Department of Forest Ecology, Mendel University in Brno, Brno 61300, Czech Republic \\ 3 Battelle-National Ecological Observatory Network (NEON), Boulder, CO 80301, USA; \\ hloescher@battelleecology.org \\ 4 Institute of Arctic and Alpine Research, University of Colorado, Boulder, CO 80301, USA \\ 5 Earth System Research Laboratory, Global Monitoring Division, National Oceanic and Atmospheric \\ Administration, Boulder, CO 80301, USA; James.H.Butler@noaa.gov \\ * Correspondence: acosta.m@czechglobe.cz
}

Received: 4 December 2019; Accepted: 2 March 2020; Published: 5 March 2020

\begin{abstract}
A growing body of scientific evidence indicates that we have entered the Anthropocene Epoch. Many assert that society has exceeded sustainable ecological planetary boundaries and that altered biogeophysical processes are no longer reversible to natural rates of ecosystem functioning. To properly and successfully address societal needs for the future, more holistic and complex methods need to be applied at various spatial and temporal scales. The increasingly interconnected nature of human and natural environments-from individuals to large megacities and entire continents and from cells through ecosystems to the biosphere as a whole (e.g., as seen in the carbon cycle)—demand new and often interdisciplinary and international approaches to address emerging global challenges. With that perspective in mind, the Czech Republic's National Climate Program was established in 1991 with the aim to understand the impact of global environmental change on society. The National Climate Program was updated in 2017 to formulate a new Climate Protection Policy. Here, we outline the multifaceted problems that climate change poses for the Czech Republic, as well as a new scientific infrastructure and approaches directed to better understanding the effects of climate change on our ecosystems, water resources, urban environment, agriculture, human health, and general economy.
\end{abstract}

Keywords: climate change; infrastructure; ecosystem; Anthropocene; Europe

\section{Introduction}

A growing body of scientific evidence indicates that we have entered the Anthropocene Epoch [1]. Exponential societal growth in recent decades has accelerated biogeophysical processes to rates unprecedented in known geological history [2]. Many assert that society has exceeded sustainable ecological planetary boundaries [3,4] and that the altered biogeophysical processes are no longer reversible to natural rates of ecosystem functioning [5]. In addition, evidence suggests that even a small change in the global temperature (e.g., $<1^{\circ} \mathrm{C}$ ) will continue to lead toward irreversible and, in many cases, negative impacts on societies and the natural systems upon which they rely [6]. The increasingly interconnected nature of human and natural environments-from individuals to large megacities and whole continents and from cells through ecosystems to the biosphere as whole (e.g., as seen in 
the carbon cycle)—demand new and often interdisciplinary and international approaches to address emerging global challenges. It is no longer sufficient to study separate processes within an ecosystem or to examine impacts of a single effect on a selected plant species. In order properly and successfully to address societal needs for the future, more holistic and complex (typically multidisciplinary and multi-methodological) approaches must be applied at various spatial and temporal scales.

The Czech Republic's National Climate Program was established in 1991 to better understand the impact of global environmental change on society [7]. Since that time, the scientific and societal imperatives to address climate change were strengthened with ratification of the 1999 Kyoto protocol [8]. In support of Kyoto, the "Strategy for Protection of the Earth's Climate System in the Czech Republic" [9] was adopted to define the Czech Republic's policy on climate change. The National Climate Program was updated in 2017 to formulate a new Climate Protection Policy (https://unfccc.int/files/na/application/ pdf/cze_climate_protection_policy_summary.pdf).

This Climate Protection Policy embodied all of the Czech Republic's international obligations while assigning equal importance to policy and strategy, adaptation, and mitigation efforts. For example, the current adaptation strategy has been adopted and is managed by the Ministry of Environment of the Czech Republic. It focuses on economic aspects related to forestry, agriculture, water resources and management, urban development, biodiversity, ecosystem services, societal health, tourism, transportation, and industry (Figure 1). Here, we outline the multifaceted problems that climate change poses for the Czech Republic, as well as a new scientific infrastructure and approaches directed to better understanding the effects of climate change on our ecosystems, water resources, urban environment, agriculture, human health, and general economy.

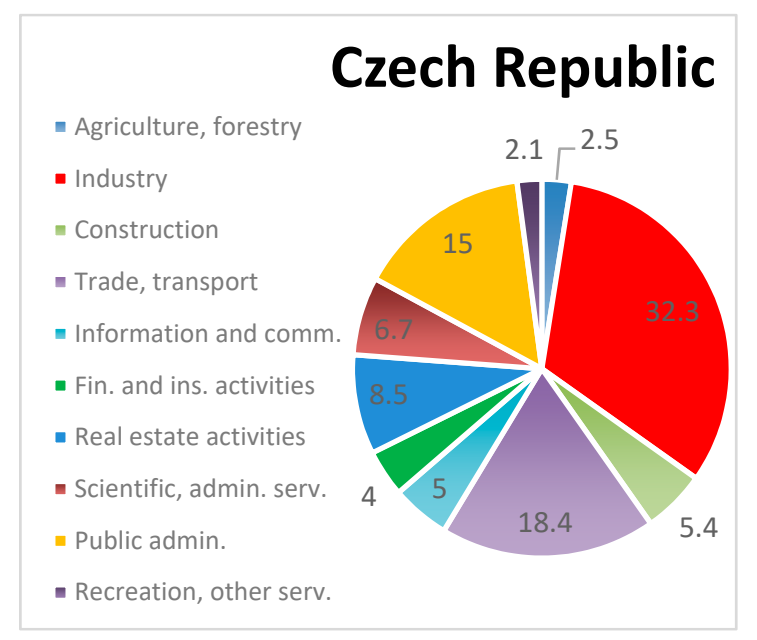

(a)

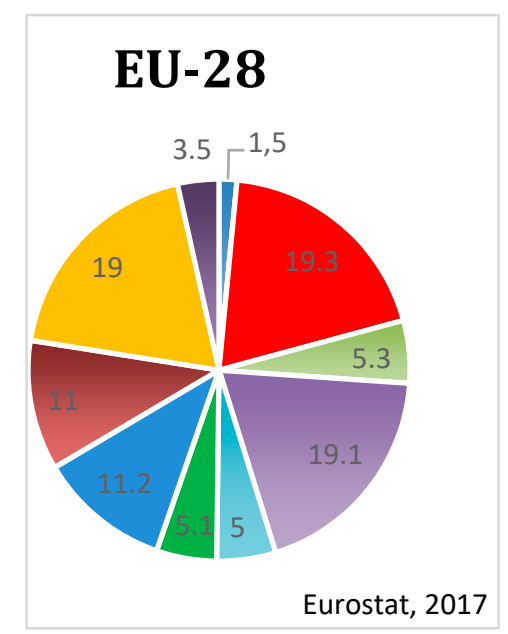

(b)

Figure 1. Composition of gross domestic product (GDP) in the Czech Republic (a) and comparison to the average of 28 countries within the European Union (b) as of 2016. Fully inclusive legend is as follows: Agriculture, forestry: agriculture, hunting, forestry, and fishing; Trade, transport: distributive trade, transport, accommodation, and food services; Information and communication; financial and insurance activities; Scientific, administrative services: professional, scientific, technical, administrative, and support services; Public administration; and Recreation, other services: arts, entertainment, recreation, and other services (Eurostat, 2017).

\subsection{Climate Change and Forestry}

Climate change already has had significant economic impact on forest management and forests compared to just 20 years ago [10]. As a proportion of GDP, the forestry and agricultural sectors (see next section) are somewhat larger in the Czech Republic (at about 2.5\%) than in the European Union (EU) as a whole (at $1.5 \%)$. This makes the Czech Republic more economically vulnerable in these sectors and particularly so if these sectors will be more affected by environmental change compared to other 
sectors. During the past century, increases in global average temperatures and $\mathrm{CO}_{2}$ concentrations, in combination with the large expanses of secondary forests, has resulted in increased tree growth rates and carbon accrual in Central Europe [11]. Increasing regional (Czech) temperatures were not associated with higher precipitation rates, however, and this had led to increasingly persistent drier conditions in Central Europe over the past several centuries [12]. Greater frequency of droughts and heatwaves has negatively impacted forest processes and associated management activities, mainly through higher tree mortality rates in forests $[13,14]$ and a combination of more extensive and/or frequent pest outbreaks [15]. A pest outbreak currently ongoing in the Jeseniky Mountains is thought to be the largest in the Czech Republic's history of modern forestry. With greater drought frequency combining with less time available for recovery [16], the strength of the forest carbon sink has been weakened, and even less carbon accrual is expected in the future [17]. Still other climate change-induced effects on additional forest processes could also impact the health of the respective ecosystems. Globally increased potential for wildfires has been identified [18], for example, and many parts of the world are seeing increase in the number and magnitude of difficult-to-control megafires. To date, however, there has been no systemic study to investigate the potential change or feedback mechanics in regards to wildfire within the Czech Republic. The potential for more fires of greater intensity is nevertheless likely to exist in the Czech Republic under future conditions given the expected higher temperatures and diminished precipitation (reducing abiotic controls) coupled with higher tree mortality, more standing and down dead wood, and more insect outbreaks [19].

\subsection{Climate Change, Agriculture, and Food Security}

The risks of food scarcity, social unrest, and increases in human migration due to rising global temperature and droughts in the world's food-producing regions are expected to grow [20-22]. In some less-developed countries, crop-damaging temperatures are also leading to increased suicide rates among farmers [23]. Climate change already has negatively affected yields of many agricultural crops, mainly as a result of increased drought and lack of irrigation water sources [24]. Future projections for Europe suggest that it will be among those parts of the world most affected by higher temperatures and drought [25]. The Czech Republic has been experiencing increased drought frequency and severity in recent decades [12], with implications for national food security. For example, there have been significant yield reductions among the main cereals and other crops within the most drought-prone regions [26]. Anthropogenic changes in these synoptic-scale weather patterns have been occurring for decades and will likely continue into the future. Although these changes are occurring slowly relative to one's lifetime, they are happening rapidly compared to changes in regional ecosystem processes. Since we have experienced these changes and have made small adaptations over the past few decades, this all appears to us as what might be termed the "new norm". However, for crops, water systems, aquifers, and air quality, the pace at which these changes have been occurring is rapid and unprecedented [27]. Moreover, because these changes do appear as such a "new norm", to achieve needed political action requires constant dialogue in order to bring about the strong and ideally immediate actions necessary to minimize potential chronic, long-term effects on food crops production [28].

\subsection{Climate Change and Water Management}

Water resources and subsequently water management are predominantly affected through the inputs (decreased precipitation and extreme precipitation) and the outputs (increased temperature-induced evapotranspiration rates and runoff). Further disruption to the water balance (at the ecosystem, regional, and countrywide scale) will be affected by (i) increased variability [25], (ii) prolonged droughts that will be punctuated in time by larger, more intense storms with increased maximum precipitation per event [22,29] and (iii) increased convective-driven precipitation events [30]. The observed temperature increases in the Czech Republic have resulted in an increase in annual evapotranspiration rates by $5 \%-10 \%$ and even by as much as $20 \%$ in winter [31]. The central and 
southeastern parts of the country are experiencing relatively poorer water balance, with more output than input as a result of lower precipitation accompanied by progressive drought. The Czech Republic's water resources are currently facing two extremes. First, minimum and average river flows are continuing to decline further from historical averages. In some cases, streams have gone dry completely. Second, and at the same time, maximum river flows and flooding have increased due to unprecedented extreme events. Drier conditions will also result in wind erosion and poorer water quality [31].

\subsection{Climate Change and Urban Development}

Due to the urban heat island effect, urban environments heat faster and store more heat than do the surrounding rural areas [32]. Average temperatures of cities with $\sim 1$ million inhabitants, such as the capital city Prague, can be $1-3{ }^{\circ} \mathrm{C}$ higher, and that difference can be as great as $12{ }^{\circ} \mathrm{C}$ during the evening [33]. The negative effect of urban heat island was manifested during the European summer heatwave in 2003, as mortality rates increased in large cities and, particularly, among older residents [34]. Climate change is also expected to bring lower quality of life and increased mortality to the cities from the combination of higher temperatures; prolonged heatwaves; poor air quality; and higher incidence of various molds, fungi, and mites [35]. Moreover, significant numbers of inhabitants in large coastal metropolitan areas threatened by rising sea levels, extreme weather conditions, and salt water intrusion are expected to migrate inland across geopolitical borders and to pose additional security risk for inland countries [36]; specifically, including the Czech Republic.

\subsection{Climate Change and Biodiversity}

The fast pace of environmental change alters climate on the synoptic scale and microscale in relation to which ecosystems have evolved to support the organisms they encompass [37]. Many animals are specific to the habitats created by these ecosystems. Ecosystems cannot move, recruit, and establish themselves (i.e., find more preferable climate) with the current rapid pace of environmental change. As a result of vegetation shift and uneven ability for organisms to migrate and adapt, a large proportion of organisms face high extinction risk [38] or must occupy replacement ecosystems having less resiliency [39]. The main impacts of climate change on biological diversity in the Czech Republic can be summarized as follow: (i) natural and seminatural ecosystems will be effected by the extinction of certain species and spreading of other ones, including pathogens and invasive alien species, toward increasing latitude and altitude; (ii) climate change will negatively affect wild animal dispersal, movement, and migration; (iii) managed artificial ecosystems will be at risk, particularly at low elevations, where they presently have been limited by water availability and where significant occurrence of newly arrived pathogens would be expected; and (iv) due to landscape patchiness and small size of some habitat patches, as well as to the relatively small size of the Czech Republic's territory, decline in and loss of some natural and seminatural ecosystems located within the country can be expected [31]. Additional risk to biodiversity ensues from land use change, whereas in the Czech Republic almost all of the landscape is dominated by human-made, managed ecosystems. The country has almost no natural or untouched ecosystems. These human-made and managed systems lack the functional complexity that fosters resiliency and the ability to cope with additional stresses [39]. Homogenization induced by land use and loss of species are already being observed in the Czech Republic [40].

\subsection{Climate Change and Health, Tourism, and Transportation}

Climate change increases risks to societal and human health, both nationally and internationally. The multidisciplinary Commission on Health and Climate Change (an international initiative by the Lancet journal to map global health impacts of climate change [41]) has concluded that climate change could be "the greatest global health opportunity of the 21st century". The associated indirect effects of climate change on the human population include increased risk of mental illness, undernutrition, allergies, cardiovascular diseases, infectious diseases, injuries, respiratory diseases, and poisoning [42]. For instance, increased average temperatures in the Czech Republic have led to significant increase 
in tick-borne encephalitis since 1982 [43]. In addition to existing and exotic vectors and pathogens facilitated by climate change, new illnesses may be introduced through increased human migration from other areas around the global that are disproportionally affected by these changes [44]. Extreme health risks related to climate change will disproportionately affect infants and the elderly, imposing additional challenges to how we sustain a diverse, vibrant, and functioning society. Due to the effects on the aging population in the Czech Republic expected to be worse than the EU average, the vulnerability of people to climate change is also expected to be greater [45].

There are both direct and indirect impacts of climate change on tourism and recreation activities. Direct impacts include extreme meteorological events that pose increased risk for tourists, including, for example, floods, landslides, storms, and long-term drought [46]. Warmer summers lead to greater costs for air-conditioning, cooling of food, and managing increased health risks [47], while warmer winters lead to increased costs to produce artificial snow and/or higher cost for travel to more distant destinations. These indirect impacts influence a given market or country's economic competitiveness. Growing frequency of extreme weather events will have similar negative impacts and will pose greater risks to the transport and energy industries and to infrastructure.

\subsection{Climate Change and Energy Security}

Industry's contribution to the Czech economy compared to that of other economies is much larger than elsewhere in the EU. This is due primarily to low energy costs and high per capita automobile production that is second only to Slovakia (Figure 1). There is a real risk to the Czech Republic's power-generating sector due to climate change, because $\sim 98 \%$ of electricity production is dependent on water availability [48]. In a recent global analysis, as much as $61 \%-74 \%$ of hydropower and $81 \%-86 \%$ of thermoelectric power plants face a need to reduce energy generation by the middle of this century, with Central Europe being among the more vulnerable regions of the world in this regard [49]. Currently, there are no apparent plans to adapt the Czech Republic to meet this challenge beyond increasing our already strong dependency on thermoelectric power generation (mainly coal and nuclear). An additional risk to energy security arises from rapidly warming frozen soils (i.e., permafrost) in other countries [50] from which a majority of the Czech Republic's imported oil and gas originates. Furthermore, the fossil fuel industry, being $\mathrm{CO}_{2}$ intensive inasmuch as it includes the automotive industry and energy production from coal, faces the dueling challenges of achieving sufficient energy production for a sustainable society while pursuing needed policies to mitigate climate change [51].

\subsection{Changing Atmospheric Chemical Composition in the Czech Republic}

Global atmospheric concentrations of the greenhouse gases (GHGs) carbon dioxide $\left(\mathrm{CO}_{2}\right)$, methane $\left(\mathrm{CH}_{4}\right)$, and nitrous oxide $\left(\mathrm{N}_{2} \mathrm{O}\right)$ have increased significantly since 1750 as a result of human activities and now far exceed pre-industrial values [52]. This increase in atmospheric $\mathrm{CO}_{2}$ is leading to the Earth's rising mean temperature and causing various feedback effects in relation to numerous ecosystems, such as were described above. Continuing research is needed to better understand these effects.

Over the past 20 years, numerous GHG studies (but mainly regarding $\mathrm{CO}_{2}$ ) at the European level (CarboEurope IP, Carbomont, and NitroEurope, among others; see www.europe-fluxdata.eu) have demonstrated insights and developed new scientific knowledge about the drivers and processes of GHG generation, transport, and exchange from the local to global scale. There are still knowledge gaps in our understanding, however, that can inform policy and actionable science. Examples concern the likes of constraining regional scale $\mathrm{CO}_{2}$ transport and exchange fluxes in the land-atmosphere system. One course of action is to establish large-scale (continental) research infrastructures to address these knowledge gaps in a consistent, traceable, and scalable way. The European Strategy Forum on Research Infrastructures (ESFRI) is directed to developing a coherent and strategic approach in order to inform policy through European research infrastructures while advancing science and informing society. The ESFRI Roadmap [53] identifies new research infrastructures pursuing pan-European interests 
and corresponds to the long-term needs and grand challenges of the European research communities that include the environmental sciences. One of the ESFRI strategic research infrastructure projects is the Integrated Carbon Observation System (ICOS). Its goals include to construct a high-precision, long-term network of stations measuring GHG fluxes from ecosystems and the oceans, as well as GHG concentrations in the atmosphere (www.icos-ri.eu [54,55]). CzechGlobe is one of the core founding partners in ICOS. Generally, the overall challenge to the society is to monitor (quantify), understand (attribute), and predict (project) the evolution of the changing environment in the context of the whole Earth's system processes. This demands a new scientific approach and synthesis that crosses disciplinary and geographic boundaries while placing particular emphasis on the changing environment.

\section{Materials and Methods-Key Elements of Research Infrastructure}

High-level research infrastructure is needed to achieve a better understanding of global change impacts and their synergies while also developing suitable mitigation strategies. The research at CzechGlobe ranges from short-term observations of plant photosynthetic processes taking place in a matter of seconds and at sub-leaf level (e.g., metabolites and photochemical reactions) up to the regional-level ground-based and remote sensing-based observations of processes taking place over years and decades.

A laboratory of metabolomics examining final or intermediate molecular products of metabolism is essential to interpreting plant physiological responses at the molecular level induced by whole-plant manipulative experiments. A huge advantage is that this method can identify large amounts of specific biomolecules related to metabolism. It helps to better understand or even identify new nonlinear metabolic-, plant growth-, and productivity-related processes under anticipated climate change conditions. Strong cooperation is developed in the area of metabolomic analysis with foreign global change institutions, such as the Ecological and Forestry Application Research Centre (CREAF) in Spain, where processes and interactions under different conditions and in contrasting natural ecosystems can be analyzed and a whole system response in a changing environment can be elucidated. Manipulative experiments are taking place both in laboratory conditions (i.e., in growth chambers with adjustable and automatic measurements of air temperature, humidity, $\mathrm{CO}_{2}$ concentration, spectral composition of radiation, etc.) and in field conditions (i.e., in open-top chambers or in lamel-growth chambers).

The CzechGlobe climate change infrastructure includes a network of ecosystem stations, with technological instrumentation for ecophysiological, plant physiological, and micrometeorological studies, along with estimation of GHG emissions under field conditions. It provides an observational framework within which other studies can be conducted (Figure 2). From these sites, CzechGlobe can provide a wide range of data, including matter and energy fluxes using eddy covariance and chamber techniques (inclusive of data from soil $\mathrm{CO}_{2}$ and woody-tissue $\mathrm{CO}_{2}$ efflux automated systems), micrometeorological data, inventory data, remote-sensing data, and more. The acquired data are used for understanding physiological processes (at cell, individual, and ecosystem levels) affecting the ability of ecosystems to bind atmospheric carbon while quantifying and describing the dynamics of ecosystem $\mathrm{CO}_{2}$ fluxes and creating and using models to generate estimations. 


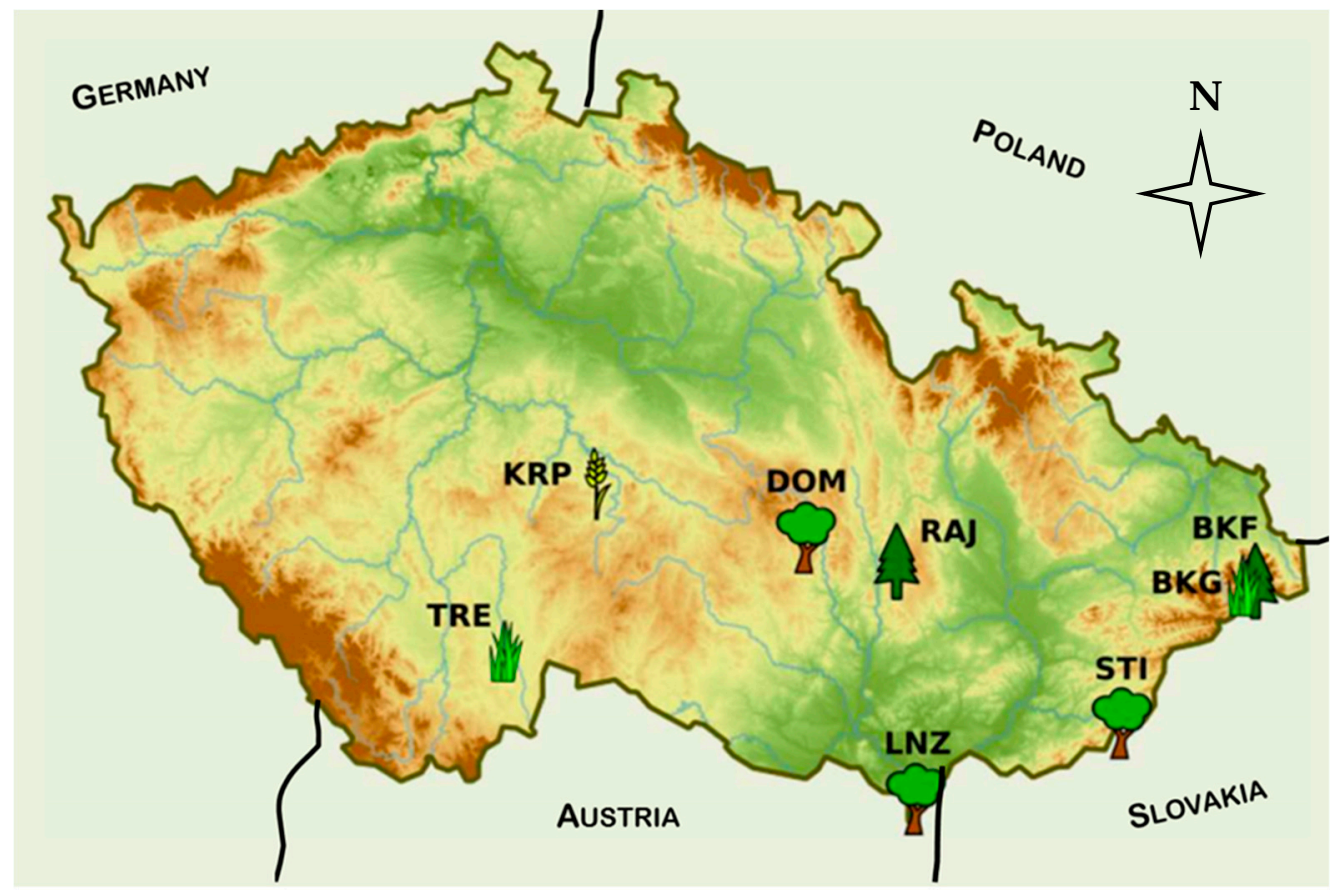

Figure 2. CzechGlobe sites (CzeCOS network). BKF: Bily Kriz spruce forest, BKG: Bily Kriz grassland, STI: Stitna beech forest, RAJ: Rajec Jestrebi spruce forest, LNZ: Lanzhot floodplain forest, DOM: Domaninek poplar plantation, KRP: Kresin agroecosystem, and TRE: Trebon wetland.

At the Domaninek site (see Table 1), a set of open-top chambers enable studying the effects of elevated $\mathrm{CO}_{2}$ on managed ecosystems in combination with the effects of drought, nutrient, and UV-radiation stress. Such manipulation is further interpreted in terms of photosynthesis, water balance, or nutrients content of important crop or short-rotation coppice species (poplar plantation). This research is coupled with the improvement and development of ecosystem models, remote-sensing methods, and other agro-climatic tools and applications. The societal relevance of this site ranges from addressing food security issues, through alternative energy sources (bioenergy) development, and to the adaptation limits of managed ecosystems to climate change. The site also is part of the ANAEE research infrastructure, CzeCOS, and the Joint Programming Initiative (FACCE MASCUR), all of which deal with impacts of climate change on agroecosystems in the Czech Republic and Europe. The Domaninek site also serves as a training center for students, business professionals, consultants, state administration and local government employees, and members of the scientific community interested in the topic of renewable resources. 
Table 1. Ecosystem stations included into the CzeCOS (ICOS) research infrastructure.

\begin{tabular}{|c|c|c|c|}
\hline Station Name (Abbreviation) & Ecosystem/Elevation (m.a.s.1.)/Age (Years) & Dominant Plant Species & Eddy-Covariance Data Since (Year) \\
\hline Lanžhot (LNZ) & Floodplain forest/155/111 & Carpinus betulus, Fraxinus augustifolia, Quercus robur- & 2015 \\
\hline Bily Kriz (BKF) & Spruce forest/875/35 & Picea abies & 2005 \\
\hline Mokre Louky (TRE) & Wetland/426/NA & Carex Acuta, Phalaris arudinacea, Glyceria Maxima & 2006 \\
\hline Stitna nad Vlari (STI) & Beech forest/550/113 & Fagus sylvatica & 2010 \\
\hline Rajec (RAJ) & Spruce forest/625/111 & Picea Abies & 2012 \\
\hline Bily Kriz (BKG) & Mountain grassland/860/NA & Nardus stricta, Festuca Rubra, Holcus Mollis & 2005 \\
\hline Kresin u Pacova (KRP) & Agroecosystem/545/NA & 10-year crop rotation & 2012 \\
\hline Domaninek (DOM) & Poplar plantation/540/15 & Poplar clone J-105 (P. nigra $\times$ P. maximowiczii) & 2011 \\
\hline
\end{tabular}


At the ecological experimental station-Bily Kriz in the Beskydy Mountains-long-term responses (over periods of years to decades) of managed forest ecosystems to environmental change are observed and evaluated. Similar to the site at Domaninek, effects of elevated $\mathrm{CO}_{2}$ concentration (in lamel-growth chambers) in combination with UV-radiation, drought, and nutrient stress are studied. A key focus is to maximize the ability of managed (spruce and mixed) forests to store carbon, while outputs of the research provide background for management practices in the forestry sector. Bily Kriz is also a part of ICOS and CzeCOS and is a prime experimental site for CzechGlobe due to its altitude and location. Very similar research is ongoing in the White Carpathians at the Experimental Station Stitna nad Vlari, where long-term monitoring of matter and energy fluxes, as well as of physiological processes, is taking place, a major aim being to better understand response of a mature beech forest ecosystem to climate change. Other ecosystem stations with long-term monitoring encompass the wetland ecosystem (Trebon), old spruce forest (Rajec), floodplain forest (Lanzhot), and agroecosystem (Kresin near Pacov).

The atmospheric station Kresin near Pacov in the Bohemian-Moravian Highlands serves as a national monitoring point for both the occurrence and remote transmission of greenhouse gases, selected pollutants, and basic meteorological characteristics. The station consists of a meteorological mast 250-m-tall, at whose various height levels atmospheric concentrations of GHGs $\left(\mathrm{CO}_{2}, \mathrm{CH}_{4}, \mathrm{CO}\right.$, $\mathrm{N}_{2} \mathrm{O}$, and $\mathrm{SF}_{6}$ ) and pollutants (tropospheric ozone, gaseous mercury, and aerosols), as well as basic meteorological characteristics (air temperature, pressure, humidity, wind speed, and direction) and height of the atmospheric boundary layer, are monitored. Its location close to others of the CzechGlobe's research facilities makes the atmospheric station significant at both the Czech and European levels.

The remote-sensing laboratory of imaging spectroscopy provides flight campaigns, data acquisition, processing, and application outputs at the regional level. It is now operating a new platform for advanced remote-sensing observations called FLIS (Flying Laboratory of Imaging Spectroscopy). FLIS consists of an airborne carrier equipped with passive (spectroradiometer) and active (laser scanner) remote-sensing systems. The key long-term objectives of the research are to (i) use LiDAR data to determine ecosystem structural parameters (e.g., tree crown shape and height) as input to radiative transfer models; (ii) elucidate the relationships between biochemical properties of plants, their structural features, and water and thermal performance; (iii) link and upscale information on the physiological functioning of individual trees with that obtained from air- and/or space-borne data; and (iv) investigate the thermal regime of landscapes and urban heat islands.

An integral part of the research infrastructure is devoted to adaptive and innovative techniques. The aim is to develop methods and technologies for cultivating photosynthetic microorganisms while maximizing the desired production abilities. The idea is to use their biological activity as the basis for the production of next-generation biofuels and valuable biological substances, such as carotenoids, unsaturated fatty acids, and various proteins. The ultimate goal, therefore, is to reduce our dependence on fossil fuels and contribute to mitigating climate change.

Last, but not least, a large part of the research infrastructure is devoted to studying the socioeconomic dimensions of climate change. Main research goals include to study (i) forces driving global changes and their effects on ecosystem services; (ii) ecosystem services, including the demands on natural services as well as the safety and vulnerability of ecosystem services provided by the changing natural environment; (iii) resilience of socioecological systems, including to analyze and assess the vulnerability of socioecological systems with respect to the impacts of global change on the sustainability of societal development and quality of life; and (iv) sustainability and management of socioecological systems, including to find alternative solutions and determine human society's optimal response to global changes.

\section{Understanding Global Climate Change: CzechGlobe}

CzechGlobe is recognized today as a leading research institution for understanding global climate change in the Czech Republic. Already a strong contributor to a broad EU understanding, CzechGlobe applies its science through international collaboration to contribute also toward a global 
understanding. CzechGlobe does this through an integrated scientific approach that interactively integrates theory, observations, models, and predictions to provide knowledge needed for society to mitigate and adapt [56]. Between the years 2009 and 2018, CzechGlobe was a part of 184 national and/or international projects, of which, almost 60 projects are still ongoing (www.CzechGlobe.cz). Since climate change impacts manifest locally but are not bound by geopolitical borders, scientific advancement depends upon addressing these complex issues on a multinational basis. Gradual, long-term socio-ecosystem changes that occur over many decades are also subject to stochastic change, such as sudden tipping points, and these, too, demand multidisciplinary approaches for understanding the cause-and-effect paradigm and better informing policy for a sustainable society moving forward. Several examples of projects pursuing such approaches are described below.

\subsection{Integrated Carbon Observation System (ICOS)}

ICOS consists of large-scale infrastructure. It exists within a special EU legal form known as a European Research Infrastructure Consortium (ERIC) and joins the efforts of 12 countries, one of those being the Czech Republic. This long-term infrastructure aims toward better understanding carbon cycle dynamics and GHG balance in the atmosphere, land ecosystems, and ocean [53]. It provides harmonized and precise scientific data that is freely and publicly accessible via its web interface (www.icos-cp.eu). ICOS has standardized measurements across Europe that are designed to inform predictive models, as well as to provide data to inform adaptation and mitigation strategies. In 2017, as many as 141 measuring stations met the high standards of ICOS, including some of those managed by CzechGlobe as a part of the Czech Carbon Observation System (CzeCOS) initiative (Table 1). One of the key measurements at each station is eddy covariance [57], and, when measured over the whole year, this provides the basis for mass-balance estimates of carbon, water, and other scalars under varying environmental conditions (Figure 3). It also provides a basis for scaling up ecosystem carbon fluxes using airborne and/or satellite remote-sensing methods to estimate regional mass balance.

\subsection{Aerosol, Clouds, and Trace Gases Research Infrastructure Network (ACTRIS)}

ACTRIS aims to provide open-access observational data for aerosols, clouds, and trace gases (www.actris.eu). ACTRIS provide basic data for primary in situ aerosol research, as well as data to explore interactive effects between air quality and health, climate change, and sustainability. Specifically, the project ACTRIS-CZ deals with the problems of regional-level air pollution and quality within the Czech Republic and, more broadly, applies to central Europe. ACTRIS is a unique infrastructure in the Czech Republic that is capable of long-term monitoring of chemical and physical processes in the atmosphere, including the long-range transport over tens to hundreds of kilometers. Since this site within the Czech Republic is located on the eastern edge of Western Europe, it plays an important role in delimiting the boundary conditions for EU modeling efforts and for inputs from long-term transport into Europe. The Czech Republic is one of the European countries where ACTRIS and ICOS activities are co-located (more at www.Actris.eu).

\subsection{Analysis and Experimentation on Ecosystems (ANAEE)}

We know that future environmental changes will have unknown and confounding effects on ecosystem processes that we currently do not understand. This is particularly true when one or more environmental factors may be working in concert or antagonistically with one another on ecosystem processes. Rather than wait until this happens in the natural environment, ANAEE is developing an experimental platform across Europe to manipulate whole ecosystems to elucidate these nonlinear, unexpected effects on ecosystems' processes before they occur in the natural world. Coupled with modeling activities, it provides a robust philosophy for interactively informing and challenging the theory-observation-model paradigm [58]. Emphasis is given to identifying and quantifying the effects of drivers of change and their interactions within environmental processes. Stakeholders can then use this information to develop targeted and informed policies and to engineer management techniques 
that will better inform efforts to mitigate and adapt to environmental changes. ANAEE is also a part of ESFRI (European Strategy Forum on Research Infrastructures) (see more at www.ANAEE.com).

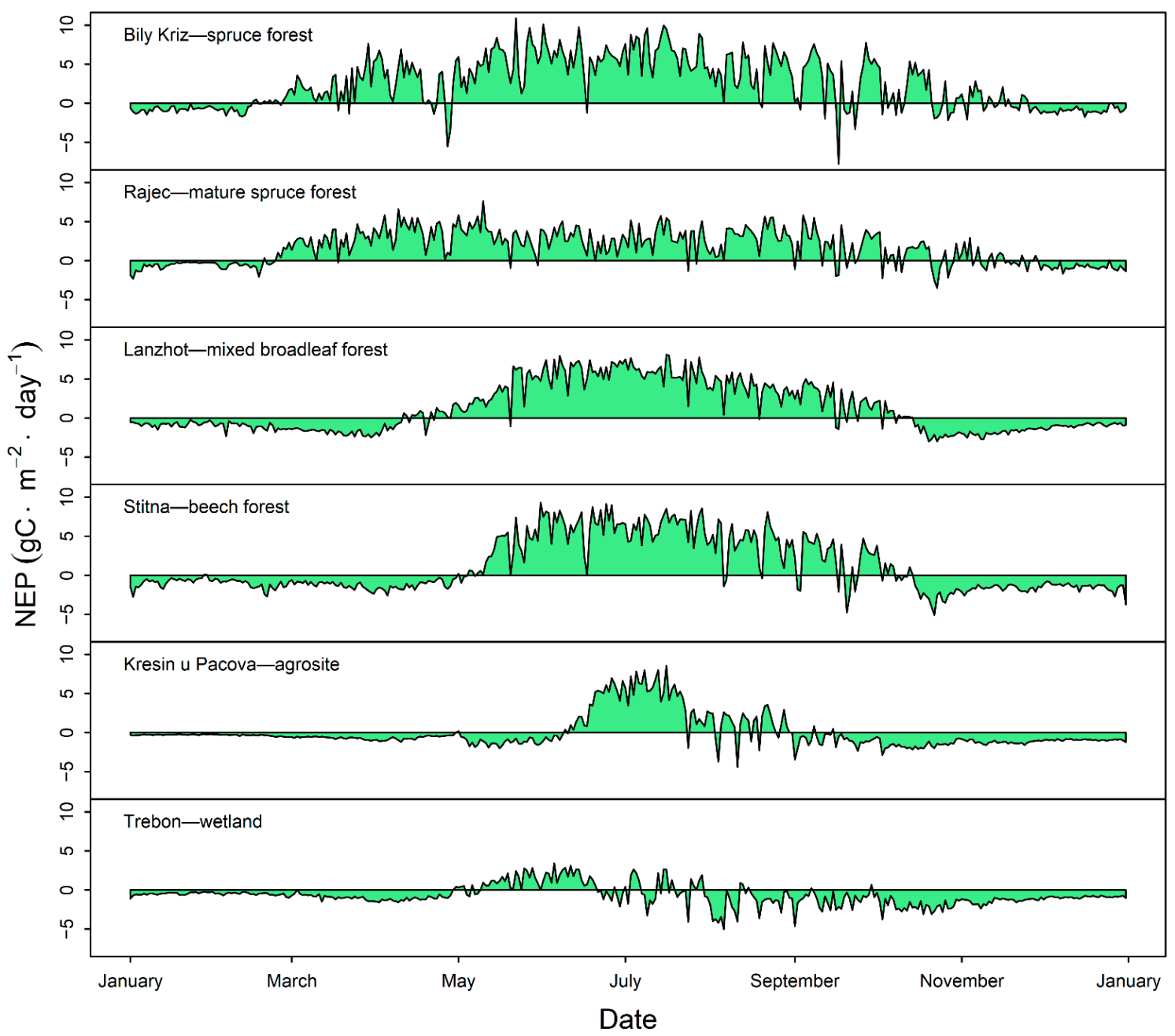

Figure 3. Comparison of annual course of net ecosystem production (NEP) for various ecosystems in the Czech Republic during the year 2018 (unpublished data Šigut et al.).

\subsection{Adaptation Strategies for Sustainable Ecosystem Services and Food Security under Adverse Environmental} Conditions (SustES)

This strong interdisciplinary project aims to create (within the experimental design to validate and in the final phase to transfer into practice) procedures enabling our ability to predict and plan to increase regional food security concurrently with strengthening landscape resiliency. The novelty of the project lies in its holistic approach to creating robust and economically acceptable adaptation solutions by integrating a range of approaches. For instance, outputs from a set of regional climate models that use future regional temperature extremes are combined with experimental designs to test the resilience and possible limits of specific plants' and/or crops' productivity that are important for food security. A regional version of the Global Biosphere Management Model (GLOBIOM), known as GLOBIUM-EU, is one of the models used to assess the potential interactions of climate change, food production, land-use change, and socioeconomics.

\subsection{InterSucho}

The InterSucho project is the outcome of cooperation among a number of scientific institutions that provide detailed, ground-based, and remote-sensing-based long-term observations. It combines more 
than a decade of experience in drought monitoring and climatology observations in the Czech Republic, Europe, and the USA. The project provides current water balance (drought) data for the Czech Republic through accessible, near real-time updates (www.InterSucho.cz). Included are site-specific data, such as soil physical properties, depth, and terrain slope. This information is integral to policymaking and successful planning efforts within several economic sectors, such as agriculture, forestry, the fishing industry, and water management. InterSucho also combines historical drought observations from many different research areas, such as meteorology, atmospheric physics, climatology, paleoclimatology, agroclimatology, dendrochronology, ecophysiology, history, and socioeconomics. The project's long-term ambition is to continuously improve drought predictions by iteratively challenging the theory-observation-model paradigm [58]. InterSucho serves a broad range of practical applications, including to provide guidance on irrigation, harvest planning, crop yield estimation, and insurance matters for the agricultural and forestry sectors.

\subsection{Supporting EU-African Cooperation on Research Infrastructures for Food Security and Greenhouse Gas Observations (SEACRIFOG)}

The global distribution of ecosystem observations is today very unevenly distributed across continents, with the bulk of available data coming from developed countries in the northern hemisphere. To reduce this spatial bias, and to support mitigation of and adaptation to climate change, the SEACRIFOG project aims to promote EU-Africa cooperation and dialogue at different levels (policy, science, and society) regarding themes of land use change, climate-smart agriculture, carbon cycle, and GHG observations. SEACRIFOG is building an integrative network for long-term and sustainable cooperation among African and European environmental research infrastructures. Among this project's outcomes will be an assessment of the aforementioned topics in Africa, as well as a road map for the way forward. CzechGlobe is one of 16 institutions participating in the project.

\subsection{Urban Adaptation to Climate Change (UrbanAdapt)}

Since large urban areas will be affected more negatively by climate change due to the urban heat island effect, UrbanAdapt is anticipating the possible impacts of climate change on cities and is informing urban adaptation strategies. It currently is focused on suitable adaptation measures for selected cities in the Czech Republic. UrbanAdapt uses an ecosystem services approach together with detailed cost-benefit economic analyses (i.e., an impact assessment approach). UrbanAdapt brings together the academic sector and nongovernmental organizations within the targeted cities. Cooperation with foreign scientific institutions is a significant part of the project. UrbanAdapt also has relevance for the policy document "Strategy on Adaptation to Climate Change in the Czech Republic" prepared at the national level (more at www.UrbanAdapt.cz).

\subsection{European Facility for Airborne Research (EUFAR AISBL)}

The use of airborne observations provides unique data to (i) scale-up ground-based observations to larger spatial (regional) scales, (ii) use ground-based observations to validate and mechanistically link to airborne measurements (providing so-called ground truth), (iii) bridge the scales between ground-based measurements and satellite-borne observations, and (iv) supply long-term observational data for remote areas where no other scientific ground-based measurements are available. CzechGlobe is one of eight European institutions participating in the EUFAR AISBL Project that operates an airborne platform (based upon a Cessna 208B Grand Caravan aircraft). This project aims to broaden EUFAR AISIBL capabilities across large European landscapes and to provide access to this platform for all European scientists, including by offering training opportunities to the user groups in airborne measurements and their applications across Europe (Figure 4). CzechGlobe contributes its broad programmatic expertise to this on a Europe-wide basis and makes research instruments available for high-quality remote-sensing applications, such as the European Space Agency Fluorescence Explorer (ESA FLEX) mission (more at www.Eufar.net). 


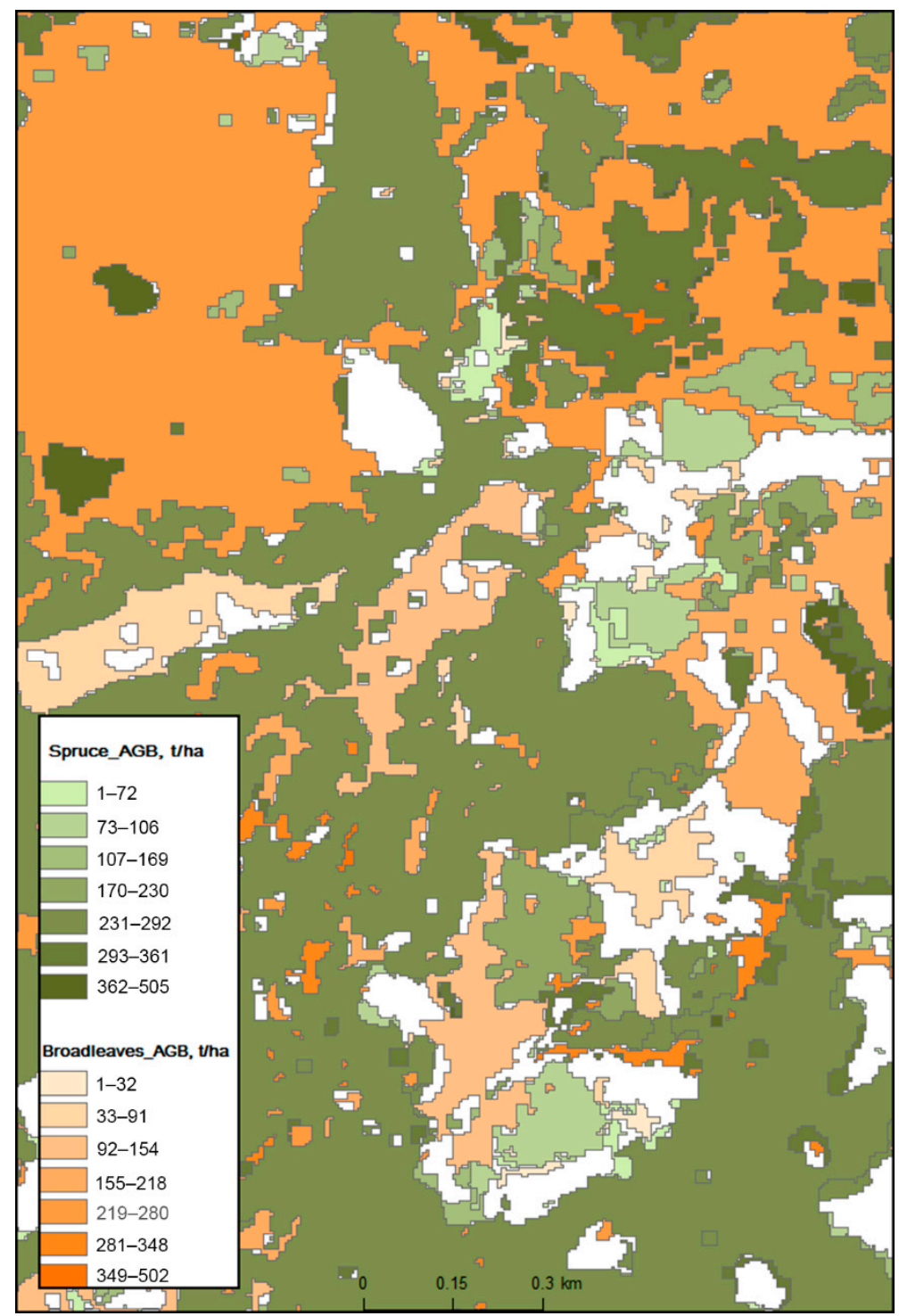

Figure 4. Map of forest aboveground biomass developed by the plot-level method from a fusion of hyperspectral and LiDAR data (Beskydy Mountains, Czech Republic). Adapted from (Brovkina et al., 2016).

\subsection{Climate Change Education Web Application}

This project aims to distill complex climate change issues to make them understandable by nonexperts and, to the greatest extent possible, by the general public. It does so by means of a web-based interactive map (providing spatial knowledge) combined with time-series data (to build temporal knowledge) for interpreting observed impacts relevant to agriculture, forestry, and other fields. It also facilitates interpretive understanding for the lay person on expected impacts across different emission and climate model scenarios. In addition, the project provides learning materials designed to be explored and to inform ecological literacy while building upon one's current level of understanding and developing the user's base of knowledge (e.g., concerning past, present, and future climate change; current and expected impacts on various economic sectors; and adaptation and mitigation scenarios). This application is designed both to inform the nonexpert and for use as a research tool. CzechGlobe is part of the European Climate Platform Initiative supporting the web application (more at www.KlimatickaZmena.cz). 


\section{Conclusions}

New knowledge and holistic understanding of the changing environment is needed to inform societal decisions for a sustainable future. A goal must be set to develop a comprehensive, policy-relevant understanding of the changing environment that encompasses its natural and human dimensions and their interactions. Potential and real social benefits from such understandings (e.g., if applied through properly designed policies) can enhance the resilience of food production, improve weather forecasting, improve forest management practices, mitigate the negative impacts of extreme weather events, and help communities to better manage the consequences of larger-scale human migration.

It is well known that process studies and models are always implicitly specific to a particular space and time scale and that it is often necessary to apply information obtained on one scale to a different scale (regional, national, or continental) in space or time. It is essential to understand these "scaling" issues across space and time, because the outcome of a targeted process or quantity can be significantly different when only small-scale or short time periods are studied and/or modeled.

Another important issue connected with changing environments and carbon cycles concerns the use of multiple data sources to improve prognostic models and forecasting in order to develop regionalized future scenarios. Regional climate models, for instance, have a standard problem in constraining precipitation variability. Different models often show opposite signs of precipitation change, but correct forecasting is essential for undertaking effective adaptation measures. Moreover, the use of long-term observations will help to validate and improve prognostics models.

CzechGlobe is investigating the manifestations and impacts of global climate change. Using the most modern techniques and instrumentation, its research is carried out in three main segments affected by global change, namely the atmosphere (climate evolution and its modeling), ecosystems (the carbon cycle and the impacts of global change on biodiversity), and socioeconomic systems (impacts on the development and behavior of society). Activities aimed at developing innovative technological processes, proposed measures for adaptation, and educational activities are integral parts of the CzechGlobe vision. In addition to its European cooperation, CzechGlobe is collaborating with international organizations sharing its vision, such as the National Ecological Observatory Network (NEON) and the Fluxnet Network of regional networks, both headquartered in the USA. The main aims of CzechGlobe's cooperation are to provide opportunities for coordinating research campaigns in order to enhance the value and precision of measurements, promote standardization of techniques and methods to increase the comparability of results, transfer results and technologies between cooperating parties, and make recommendations for improving network design and coordination among national and regional environmental change programs.

One of CzechGlobe's main goals today is to foster capacity building in ecosystem science by providing facilities and structuring tools for the ecological and ecosystem research community in order to strengthen the European research area. CzechGlobe has an infrastructure equipped with high-performance instrumentation and information technology tools.

CzechGlobe is currently experiencing a rapid expansion of both specific (local) and broad (regional to global) research topics and projects. Naturally, CzechGlobe is also an increasingly active participant in the international institutional network, interacting not only with European countries but also with countries from other continents (America, Africa, and Asia). This is enabled by growing public awareness as to the seriousness of global problems, which are increasingly manifested at local levels. Thus, increased societal needs to address problems arising from global (un)sustainability are also reflected in increased financial allocation for global climate change research at national, as well as EU, levels. Since the world is interconnected in ways unprecedented in human history, it is impossible today to address complex global problems interconnected in terms of their origins, manifestations, and impacts without international cooperation. Therefore, continuing international cooperation with scientific institutions but, also, with policymakers and local authorities, is essential. 
Author Contributions: M.A. conceived the idea for the study. M.A, M.P., K.H., and D.J. designed the study. M.A., K.H., A.A., and H.W.L. carried out literature research and analyzed the data. M.A., A.A., M.P., K.H., H.W.L., J.H.B., D.J., and M.V.M. All authors have read and agreed to the published version of the manuscript.

Funding: This work was supported by the Ministry of Education, Youth and Sports of the Czech Republic within the CzeCOS Program, grant number LM2015061. Acknowledgement is also given to the European Commission for support through the project "Supporting EU-African Cooperation on Research Infrastructures for Food Security and Greenhouse Gas Observations" (SEACRIFOG; project ID 730995), Czech Mountain Forests Climate-Smart Forestry - CZECLIMO (LTC17007), Program Inter-excelence and to the National Science Foundation-Science Across Virtual Institutes (ICER-1321595) for its ongoing support. The National Ecological Observatory Network (NEON) is a project funded by the NSF and managed under a cooperative support agreement (1029808) by Battelle. Any opinions, findings, and conclusions or recommendations expressed in this material are those of the authors and do not necessarily reflect the views of the NSF.

Conflicts of Interest: The authors declare no conflict of interest.

\section{References}

1. Steffen, W.; Broadgate, W.; Deutsch, L.; Gaffney, O.; Ludwig, C. The trajectory of the Anthropocene: The great acceleration. Anthr. Rev. 2015, 2, 81-98. [CrossRef]

2. Naafs, B.D.A.; Castro, J.M.; De Gea, G.A.; Quijano, M.L.; Schmidt, D.N.; Pancost, R.D. Gradual and sustained carbon dioxide release during Aptian Oceanic Anoxic Event 1a. Nat. Geosci. 2016, 9, 135-139. [CrossRef]

3. Rockström, J.; Steffen, W.; Noone, K.; Persson, Å.; Chapin, F.S.; Lambin, E.F.; Lenton, T.M.; Scheffer, M.; Folke, C.; Schellnhuber, H.J.; et al. A safe operating space for humanity. Nature 2009, 461, 472. [CrossRef] [PubMed]

4. Barnosky, A.D.; Hadly, E.A.; Bascompte, J.; Berlow, E.L.; Brown, J.H.; Fortelius, M.; Getz, W.M.; Harte, J.; Hastings, A.; Marquet, P.A.; et al. Approaching a state shift in Earth's biosphere. Nature 2012, 486, 52-58. [CrossRef] [PubMed]

5. Drijfhout, S.; Bathiany, S.; Beaulieu, C.; Brovkin, V.; Claussen, M.; Huntingford, C.; Scheffer, M.; Sgubin, G.; Swingedouw, D. Catalogue of abrupt shifts in Intergovernmental Panel on Climate Change climate models. Proc. Natl. Acad. Sci. USA 2015, 112, E5777-E5786. [CrossRef] [PubMed]

6. Hansen, J.; Sato, M.; Kharecha, P.; Von Schuckmann, K.; Beerling, D.J.; Cao, J.; Marcott, S.; Masson-Delmotte, V.; Prather, M.J.; Rohling, E.J.; et al. Young People's Burden: Requirement of Negative CO2 Emissions. Earth Syst. Dyn. 2017, 8, 577-616. [CrossRef]

7. Moldan, B.; Lapin, M.; Nemešová, I.; Sobíšek, B. Národní klimatický program ČSFR: Problémy, záměry a cíle; Národní klimatický program ČSFR. s. 5-53; Český hydrometeorologický ústav: Praha, Czech Republic, 1991; ISBN 80-900206-5-8.

8. Grubb, M.; Vrolijk, C.; Brack, D.; Forsyth, T.; Lanchbery, J.; Missfield, F. The Kyoto Protocol: A Guide and Assessment; Royal Institute of International Affairs: London, UK, 1999; Volume 10.

9. Pretel, J. Strategie ochrany klimatu v České republice; Materiál MŽP ČR pro jednání vlády ČR: Praha, MŽP, Czech Republic, 1998; Volume 4, pp. 113-117. Available online: http://www.cmes.cz/cs/node/390 (accessed on 30 May 1998). (In Czech)

10. Vinš, B. Dopady možné změny klimatu na lesy v České republice; Český hydrometeorologický ústav: Praha, Czech Republic, 1996; ISBN 80-85813-29-7.

11. Pretzsch, H.; Biber, P.; Schütze, G.; Uhl, E.; Rötzer, T. Forest stand growth dynamics in Central Europe have accelerated since 1870. Nat. Commun. 2014, 5, 4967. [CrossRef]

12. Brázdil, R.; Dobrovolný, P.; Trnka, M.; Kotyza, O.; Řezníčková, L.; Valášek, H.; Zahradníček, P.; Štěpánek, P. Droughts in the Czech Lands, 1090-2012 AD. Clim. Past 2013, 9, 1985-2002. [CrossRef]

13. Anderegg, W.R.L.; Flint, A.; Huang, C.; Flint, L.; Berry, J.A.; Davis, F.W.; Sperry, J.S.; Field, C.B. Tree mortality predicted from drought-induced vascular damage. Nat. Geosci. 2015, 8, 367-371. [CrossRef]

14. Anderegg, W.R.L.; Kane, J.M.; Anderegg, L.D.L. Consequences of widespread tree mortality triggered by drought and temperature stress. Nat. Clim. Chang. 2013, 3, 30-36. [CrossRef]

15. Hlásny, T.; Holuša, J.; Štěpánek, P.; Turčáni, M.; Polčák, N. Expected impacts of climate change on forests Czech Republic as a case study. J. For. Sci. 2011, 57, 422-431. [CrossRef]

16. Schwalm, C.R.; Anderegg, W.R.L.; Michalak, A.M.; Fisher, J.B.; Biondi, F.; Koch, G.; Litvak, M.; Ogle, K.; Shaw, J.D.; Wolf, A.; et al. Global patterns of drought recovery. Nature 2017, 548, 202-205. [CrossRef] [PubMed] 
17. Allen, C.D.; Breshears, D.D.; McDowell, N.G. On underestimation of global vulnerability to tree mortality and forest die-off from hotter drought in the Anthropocene. Ecosphere 2015, 129. [CrossRef]

18. Jolly, W.M.; Cochrane, M.A.; Freeborn, P.H.; Holden, Z.A.; Brown, T.J.; Williamson, G.J.; Bowman, D.M.J.S. Climate-induced variations in global wildfire danger from 1979 to 2013 . Nat. Commun. 2015, 6, 7537. [CrossRef]

19. Abatzoglou, J.T.; Williams, A.P. Impact of anthropogenic climate change on wildfire across western US forests. Proc. Natl. Acad. Sci. USA 2016, 113, 11770-11775. [CrossRef]

20. Jones, B.T.; Mattiacci, E.; Braumoeller, B.F. Food scarcity and state vulnerability: Unpacking the link between climate variability and violent unrest. J. Peace Res. 2017, 54, 335-350. [CrossRef]

21. Deutsch, C.A.; Tewksbury, J.J.; Tigchelaar, M.; Battisti, D.S.; Merrill, S.C.; Huey, R.B.; Naylor, R.L. Increase in crop losses to insect pests in a warming climate. Science (80-.) 2018, 361, 916-919. [CrossRef]

22. Zhao, C.; Liu, B.; Piao, S.; Wang, X.; Lobell, D.B.; Huang, Y.; Huang, M.; Yao, Y.; Bassuk, S.; Ciais, P.; et al. Temperature increase reduces global yields of major crops in four independent estimates. Proc. Natl. Acad. Sci. USA 2017, 114, 9326-9331. [CrossRef]

23. Carleton, T.A. Crop-damaging temperatures increase suicide rates in India. Proc. Natl. Acad. Sci. USA 2017, 114, 8746-8751. [CrossRef]

24. Lesk, C.; Rowhani, P.; Ramankutty, N. Influence of extreme weather disasters on global crop production. Nature 2016, 529, 84-87. [CrossRef]

25. IPCC. Summary for Policymakers. In Global Warming of $1.5^{\circ} \mathrm{C}$.; An IPCC Special Report on the impacts of global warming of $1.5^{\circ} \mathrm{C}$ above pre-industrial levels and related global greenhouse gas emission pathways, in the context of strengthening the global response to the threat of climate change, sustainable development, and efforts to eradicate poverty; Masson-Delmotte, V., Zhai, P., Pörtner, H.-O., Roberts, D., Skea, J., Shukla, P.R., Pirani, A., Moufouma-Okia, W., Péan, C., Pidcock, R., et al., Eds.; World Meteorological Organization: Geneva, Switzerland, 2018; p. 32.

26. Hlavinka, P.; Trnka, M.; Semera, D.; Moz, M.; Dubrovsky, M.; Žalud, Z.; Možný, M. Effect of drought on yield variability of key crops in Czech Republic. Agric. For. Meteorol. 2009, 149, 431-442. [CrossRef]

27. Challinor, A.J.; Koehler, A.-K.; Ramirez-Villegas, J.; Whitfield, S.; Das, B. Current warming will reduce yields unless maize breeding and seed systems adapt immediately. Nat. Clim. Chang. 2016, 6, 954-958. [CrossRef]

28. Chabbi, A.; Lehmann, J.; Ciais, P.; Loescher, H.W.; Cotrufo, M.F.; Don, A.; SanClements, M.; Schipper, L.; Six, J.; Smith, P.; et al. Aligning agriculture and climate policy. Nat. Clim. Chang. 2017, 7, 307-309. [CrossRef]

29. Stadtherr, L.; Coumou, D.; Petoukhov, V.; Petri, S.; Rahmstorf, S. Record Balkan floods of 2014 linked to planetary wave resonance. Sci. Adv. 2016, 2, e1501428. [CrossRef] [PubMed]

30. Ye, H.; Fetzer, E.J.; Wong, S.; Lambrigtsen, B.H. Rapid decadal convective precipitation increase over Eurasia during the last three decades of the 20th century. Sci. Adv. 2017, 3, e1600944. [CrossRef]

31. Pretel, J.; Metelka, L.; Daňhelka, J.; Rožnovský, J.; Janouš, D.; Tolasz, R.; Kliegrová, S.; Pechková, J.; Kulasová, B.; Řičicová, P.; et al. Zpřesnění dosavadních odhadů dopadů klimatické změny v sektorech vodního hospodářství, zemědělství a lesnictví a návrhy adaptačních opatření. 2011, pp. 1-67. Available online: http://invenio.nusl.cz/record/125580/ (accessed on 10 October 2012).

32. Leal Filho, W.; Echevarria Icaza, L.; Neht, A.; Klavins, M.; Morgan, E.A. Coping with the impacts of urban heat islands. A literature based study on understanding urban heat vulnerability and the need for resilience in cities in a global climate change context. J. Clean. Prod. 2018, 171, 1140-1149. [CrossRef]

33. Voogt, J.A. Urban heat island. In Encyclopedia of Global Environmental Change; Munn, T., Ed.; John Wiley \& Sons, Ltd.: Chichester, UK, 2002; pp. 660-666.

34. Robine, J.M.; Cheung, S.L.K.; Le Roy, S.; Van Oyen, H.; Griffiths, C.; Michel, J.P.; Herrmann, F.R. Death toll exceeded 70,000 in Europe during the summer of 2003. Comptes Rendus Biol. 2008, 331, 171-178. [CrossRef]

35. Matthews, T.K.R.; Wilby, R.L.; Murphy, C. Communicating the deadly consequences of global warming for human heat stress. Proc. Natl. Acad. Sci. USA 2017, 114, 3861-3866. [CrossRef]

36. Hauer, M.E. Migration induced by sea-level rise could reshape the US population landscape. Nat. Clim. Chang. 2017, 7, 321-325. [CrossRef]

37. Lawler, J.J.; Ackerly, D.D.; Albano, C.M.; Anderson, M.G.; Dobrowski, S.Z.; Gill, J.L.; Heller, N.E.; Pressey, R.L.; Sanderson, E.W.; Weiss, S.B. The theory behind, and the challenges of, conserving nature's stage in a time of rapid change. Conserv. Biol. 2015, 29, 618-629. [CrossRef] 
38. Urban, M.C. Accelerating extinction risk from climate change. Science (80-.) 2015, 348, 571-573. [CrossRef] [PubMed]

39. Chapin, F.S., III; Folke, C.; Kofinas, G.P. A framework for understanding change. In Principles of Ecosystem Stewardship; Springer: New York, NY, USA, 2009; p. 401.

40. Billeter, R.; Liira, J.; Bailey, D.; Bugter, R.; Arens, P.; Augenstein, I.; Aviron, S.; Baudry, J.; Bukacek, R.; Burel, F.; et al. Indicators for biodiversity in agricultural landscapes: A pan-European study. J. Appl. Ecol. 2008, 45, 141-150. [CrossRef]

41. Watts, N.; Amann, M.; Arnell, N.; Ayeb-Karlsson, S.; Belesova, K.; Berry, H.; Bouley, T.; Boykoff, M.; Byass, P.; Cai, W.; et al. The 2018 report of the Lancet Countdown on health and climate change: Shaping the health of nations for centuries to come. Lancet 2018, 392, 2479-2514. [CrossRef]

42. Watts, N.; Adger, W.N.; Agnolucci, P.; Blackstock, J.; Byass, P.; Cai, W.; Chaytor, S.; Colbourn, T.; Collins, M.; Cooper, A.; et al. Health and climate change: Policy responses to protect public health. Lancet 2015, 386, 1861-1914. [CrossRef]

43. Kř́ž , B.; Kott, I.; Daniel, M.; Vrálbík, T.; Beneš, Č. Impact of climate changes on the incidence of tick-borne encephalitis in the Czech Republic in 1982-2011. Epidemiol. Mikrobiol. Imunol. 2015, 64, 24-32.

44. Kelley, C.P.; Mohtadi, S.; Cane, M.A.; Seager, R.; Kushnir, Y. Climate change in the Fertile Crescent and implications of the recent Syrian drought. Proc. Natl. Acad. Sci. USA 2015, 112, 3241-3246. [CrossRef]

45. The Czech Republic in 2030: The Future Demographic; Euromonitor International: London, UK, 2014.

46. UNDP. Sustaining Human Progress: Reducing Vulnerabilities and Building Resilience; Human Development Report; UNDP: New York, NY, USA, 2014; ISBN 978-92-1-126340-4.

47. Davis, L.W.; Gertler, P.J. Contribution of air conditioning adoption to future energy use under global warming. Proc. Natl. Acad. Sci. USA 2015, 112, 5962-5967. [CrossRef]

48. International Energy Statistics [WWW Document], 2015, US EIA. Available online: http://www.eia.gov/ cfapps/ipdbproject/IEDIndex3.cfm?tid=2\&pid=2\&aid=12 (accessed on 30 April 2015).

49. van Vliet, M.T.H.; Wiberg, D.; Leduc, S.; Riahi, K. Power-generation system vulnerability and adaptation to changes in climate and water resources. Nat. Clim. Chang. 2016, 6, 375-380. [CrossRef]

50. Shiklomanov, N.I.; Streletskiy, D.A.; Swales, T.B.; Kokore, V.A. Climate Change and Stability of Urban Infrastructure in Russian Permafrost Regions: Prognostic Assessment based on GCM Climate Projections. Geogr. Rev. 2017, 107, 125-142. [CrossRef]

51. Rockström, J.; Gaffney, O.; Rogelj, J.; Meinshausen, M.; Nakicenovic, N.; Schellnhuber, J.H. A roadmap for rapid decarbonization. Science (80) 2017, 355, 1269-1271. [CrossRef]

52. Stocker, T.F.; Qin, D.; Plattner, G.-K.; Tignor, M.; Allen, S.K.; Boschung, J.; Nauels, A.; Xia, Y.; Bex, V.; Midgley, P.M. IPCC, 2013: Climate Change 2013: The Physical Science Basis; Contribution of Working Group I to the Fifth Assessment Report of the Intergovernmental Panel on Climate Change; Cambridge University Press: Cambridge, UK; New York, NY, USA, 2013. [CrossRef]

53. EU. Directorate-General for Research and Innovation; ESFRI Annual report 2016; EU: Brussels, Belgium, 2016.

54. Franz, D.; Acosta, M.; Altimir, N.; Arriga, N.; Arrouays, D.; Aubinet, M.; Aurela, M.; Ayres, E.; López-Ballesteros, A.; Barbaste, M.; et al. Towards long-term standardised carbon and greenhouse gas observations for monitoring Europe's terrestrial ecosystems: A review. Int. Agrophysics 2018, 32, 439-455. [CrossRef]

55. Gielen, B.; Janssens, I.A.; Beeck, M.O.; Loustau, D.; Cuelemans, R.; Jordan, A.; Papale, D. Integration Carbon Observation System (ICOS): An infrastructure to monitor the European greenhouse gas balance. In Terrestrial Ecosystem Research Infrastructures: Challenges and Opportunities; Chabbi, A., Loescher, H.W., Eds.; CRC Press, Taylor \& Francis Group: Boca Raton, FL, USA, 2017; pp. 506-520. ISBN 9781498751315.

56. Loescher, H.W.; Kelly, E.; Lea, R. National Ecological Observatory Network: Beginnings, Programmatic and Scientific Challenges, and Ecological Forecasting. In Terrestrial Ecosystem Research Infrastructures: Challenges and Opportunities; Chabbi, A., Loescher, H.W., Eds.; CRC Press, Taylor \& Francis Group: Boca Raton, FL, USA, 2017; pp. 27-48, ISBN 9781498751315. 
57. Loescher, H.W.; Law, B.E.; Mahrt, L.; Hollinger, D.Y.; Campbell, J.; Wofsy, S.C. Uncertainties in, and interpretation of, carbon flux estimates using the eddy covariance technique. J. Geophys. Res. Atmos. 2006, 111. [CrossRef]

58. Chabbi, A.; Loescher, H.W.; Tye, M.; Hudnut, D. Integrated experimental research infrastructures as a paradigm shift to face an uncertain world. In Terrestrial Ecosystem Research Infrastructures: Challenges and Opportunities; Chabbi, A., Loescher, H.W., Eds.; CRC Press, Taylor \& Francis Group: Boca Raton, FL, USA, 2017; pp. 3-23, ISBN 9781498751315.

(C) 2020 by the authors. Licensee MDPI, Basel, Switzerland. This article is an open access article distributed under the terms and conditions of the Creative Commons Attribution (CC BY) license (http://creativecommons.org/licenses/by/4.0/). 